\title{
Establishment of three cell lines from Chinese giant salamander and their sensitivities to the wild-type and recombinant ranavirus
}

\author{
Jiang-Di Yuan, Zhong-Yuan Chen, Xing Huang, Xiao-Chan Gao and Qi-Ya Zhang*
}

\begin{abstract}
Known as lethal pathogens, Ranaviruses have been identified in diseased fish, amphibians (including Chinese giant salamander Andrias davidianus, the world's largest amphibian) and reptiles, causing organ necrosis and systemic hemorrhage. Here, three Chinese giant salamander cell lines, thymus cell line (GSTC), spleen cell line (GSSC) and kidney cell line (GSKC) were initially established. Their sensitivities to ranaviruses, wild-type Andrias davidianus ranavirus (ADRV) and recombinant Rana grylio virus carrying EGFP gene (rRGV-EGFP) were tested. Temporal transcription pattern of ranavirus major capsid protein (MCP), fluorescence and electron microscopy observations showed that both the wild-type and recombinant ranavirus could replicate in the cell lines.
\end{abstract}

\section{Introduction, methods and results}

The Chinese giant salamander Andrias davidianus is the largest extant species of amphibian in the world and is often crowned as a living fossil [1]. The wild Chinese giant salamanders are on the verge of extinction, arousing wide research interest in its conservation [2]. Unfortunately, the prevalence of iridoviruses (including ranavirus and lymphocystis virus) infections is increasingly associated with major declines of amphibian species worldwide, causing extensive damage to aquaculture [3-7]. Ranaviruses are icosahedral DNA viruses, and are recognized as major viral pathogens of ectothermic vertebrates, namely fish, amphibians and reptiles [8-10]. Ranaviruses have been identified in diseased Chinese giant salamanders, such as Andria davidianus ranavirus (ADRV), which pose a serious threat to its population [11-14]. Another ranavirus strain, Rana grylio virus (RGV) is a pathogenic agent that causes lethal disease in cultured frogs (Rana grylio), which is the first isolated ranavirus in China [15]. In recent years, several recombinant RGV, including $\Delta$ TK-RGV, $\Delta 67 \mathrm{R}-\mathrm{RGV}$ and i53R-RGV-lacIO were constructed in our laboratory [16-18]. Recombinant virus technology has provided novel approaches for

\footnotetext{
* Correspondence: zhangqy@ihb.ac.cn

State Key Laboratory of Freshwater Ecology and Biotechnology, Institute of Hydrobiology, Chinese Academy of Sciences, Graduate University of Chinese Academy of Sciences, Wuhan 430072, China
}

unraveling virus-host interactions and host antiviral immune response [19].

Cell culture is essential for virus replication and isolation, because they are obligate intracellular agents [20]. A cell culture-based technique has been popular for studying virus infection mechanisms, viral gene functions and virus-host interactions in aquaculture animals, and it is regarded as the "gold standard" for detection and diagnosis of viral pathogens [21,22]. Besides, the cultured cells have been used to replace live animals in testing agents in virology, pharmacology, toxicology, etc. [23]. However, in contrast to fish, from which various cell lines have been established [24], few permanent cell lines have been established from the Amphibian, Order Caudata $[25,26]$. To our knowledge, no cell line from Chinese giant salamanders is currently available. Therefore, we attempted to establish different cell lines from the Chinese giant salamander and to investigate their sensitivities to the wild-type and recombinant ranavirus.

In the present study, one-year-old healthy Chinese giant salamanders were anesthetized, killed and wiped with $75 \mathrm{v} / \mathrm{v}$ ethanol, and the thymus, spleen and kidney tissues were removed for primary culture. All animal procedures were conducted in accordance with the recommendations in the Regulations for the Administration of Affairs Concerning Experimental Animals of China, and all efforts were made to minimize suffering. 
The tissues were immersed in $70 \% \mathrm{v} / \mathrm{v}$ ethanol for $30 \mathrm{~s}$, washed three times with sterile phosphate-buffered saline and minced thoroughly with scissors, followed by incubation in glass plates with TC199 medium containing 1000 units $\mathrm{mL}^{-1}$ penicillin (Sigma) and $1000 \mu \mathrm{g} / \mathrm{mL}$ streptomycin (Sigma) for $1 \mathrm{~h}$. The minced tissues were attached to $25 \mathrm{~cm}^{2}$ cell culture flasks with $4 \mathrm{~mL}$ of TC199 medium supplemented with $20 \%$ fetal bovine serum (FBS), 100 units $/ \mathrm{mL}$ penicillin and $100 \mu \mathrm{g} / \mathrm{mL}$ streptomycin by a tissue explant method. The cell cultures were maintained at $25{ }^{\circ} \mathrm{C}$, and one half of the growth medium was changed every 4 days. The primary cells emigrated from tissues after a month, and were heterogeneous in morphology. The serum concentration was changed to $10 \%$ after the cells reached $80 \%$ confluence. Thus the Chinese giant salamander thymus cell line (GSTC), spleen cell line (GSSC), and kidney cell line (GSKC) were established after subcultured for more than 60 passages. As shown in Figure 1A, three cell lines all exhibited epitheliallike morphology. The three cell lines at passages of 10, 24 and 58 were cryopreserved and recovered successfully, respectively, according to methods previously described [27]. Briefly, after being subcultured for three days, the cells were trypsinized and suspended in $3 \mathrm{~mL}$ TC199 medium containing 10\% dimethyl sulfoxide and $20 \%$ FBS. The cell suspensions were transferred to a $2-\mathrm{mL}$ cryovial, kept in a foamy box and stored in $-80{ }^{\circ} \mathrm{C}$ quickly. GSTC was taken as a model for further characterization. The effects of incubation temperature on GSTC cell growth were studied at the 45th passage level. GSTC cells were inoculated into a 24-well plate at a density of $1.3 \times 10^{5}$ cells/well and incubated at $15,20,25$ and $30{ }^{\circ} \mathrm{C}$, respectively. Triplicate wells of cells at each temperature were trypsinized and counted using a hemocytometer every two days. Figure 1B shows that GSTC cells grew best at $30{ }^{\circ} \mathrm{C}$ in the first 4 days, and 5 days later the highest growth rate was obtained at $25^{\circ} \mathrm{C}$. The other two cell lines (GSSC and GSKC) grew best at $25{ }^{\circ} \mathrm{C}$ too. Chromosome preparations were obtained from the cells (such as GSTC, at passage 45) using a method described previously [24]. Hundred photographed cells at metaphase were counted and the karyotype was analyzed. The chromosome numbers varied from 28 to 102, with a distinct peak at 50. The metaphase displayed the karyotype morphology (Figure 1C) consisting of 12 pairs of metacentrics $(\mathrm{m}), 11$ pairs of submetacentrics $(\mathrm{sm}), 1$ pair of telocentrics $(\mathrm{t})$ and 1 pair of subtelocentrics (st): $(2 n=24 m+22 s m+2 t+2 s t)$. The chromosome analysis revealed that GSTC has a diploid karyotype with $2 n=50$ (Figure 1D). Two other cell lines had a near-diploid karyotype.

To test the susceptibilities of GSTC, GSSC and GSKC cells to ADRV, three cell lines were infected with the virus respectively. Cells were seeded into 6-well plates at a density of $6 \times 10^{5}$ cells/well in TC199 medium containing
5\% FBS and $20 \mathrm{mmol} / \mathrm{L} N$-2-hydroxyethylpiperazine- $N$-2'ethanesulfonic acid. After incubation overnight at $25{ }^{\circ} \mathrm{C}$, the cells were challenged with ADRV at multiplicities of infection of 0.01 . The virus was removed after absorption for $1 \mathrm{~h}$, and then $1 \mathrm{~mL}$ fresh medium was added. Cytopathic effects (CPE) caused by viruses were observed daily under an inverted light microscope (Leica Microsystems). The supernatant was harvested at 7 days post infection and used for virus titration study as described previously [27]. The viral titer of ADRV in GSTC cells was detected $\left(10^{8.4} \mathrm{TCID}_{50} / \mathrm{mL}\right)$, which was higher than that in GSSC cells $\left(10^{8.0} \mathrm{TCID}_{50} / \mathrm{mL}\right)$ and GSKC cells $\left(10^{7.6} \mathrm{TCID}_{50} / \mathrm{mL}\right)$. The development of CPE in ADRV-infected GSTC cells was persistently observed. The infected cells exhibited localized morphological changes such as cell shrinkage and aggregation at 18 hours post infection (hpi). As CPE developed, the aggregated cells became disintegrated and clear CPE were visible at $24 \mathrm{hpi}$. The infected cells were degenerated and detached, and plaques could be observed at 36 hpi. However, there was no CPE in mock-infected cells all the time (Figure 2A). To confirm the susceptibility of the cells to ADRV further, reverse transcription polymerase chain reaction (RT-PCR) was performed to study the temporal pattern of ADRV major capsid protein (MCP) transcription. Total RNA were extracted from mock-infected or infected GSTC cells at $2,4,6,8,10,12,24$ and 48 hpi as we previously did. A pair of primers targeted to the MCP gene (forward primer: 5'TCTCTGGAGAAGAAGAA3'; reverse primer: 5'GACTTGGCCACTTATGAC3') [11] was used for PCR. The PCR program was carried out as follows: $4 \mathrm{~min}$ at $94{ }^{\circ} \mathrm{C}$ and then $30 \mathrm{~s}$ at $94{ }^{\circ} \mathrm{C}$, $30 \mathrm{~s}$ at $50{ }^{\circ} \mathrm{C}, 45 \mathrm{~s}$ at $72{ }^{\circ} \mathrm{C}$ for 32 cycles, followed by $72{ }^{\circ} \mathrm{C}$ for $5 \mathrm{~min}$. PCR products were sequenced and compared with the MCP sequences of ADRV. As shown in Figure 2B, a specific 532 bp DNA fragment could be amplified in ADRV-infected GSTC cells from $6 \mathrm{hpi}$, and the sequences were $100 \%$ identical to the corresponding nucleotide sequences from ADRV. The expression of MCP gene increased from 6 to $24 \mathrm{hpi}$, while the identical band could not be detected in the uninfected cells or infected cells at 2 and 4 hpi (Figure 2B). The combination of microscopic observation and RT-PCR analysis showed that GSTC cells can support the wild-type ranavirus, Andria davidianus ranavirus (ADRV) replication.

The recombinant Rana grylio virus carrying enhanced green fluorescent protein (rRGV-EGFP) was constructed by inserting the EGFP gene into $67 \mathrm{R}$ gene locus of RGV as described previously [18]. GSTC cells were infected with rRGV-EGFP as described above. The CPE was illustrated using a combination of light and fluorescence microscopy (Leica Microsystems). Infections with recombinant ranavirus rRGV-EGFP and wild-type ranavirus ADRV induced similar cytopathic characteristics 


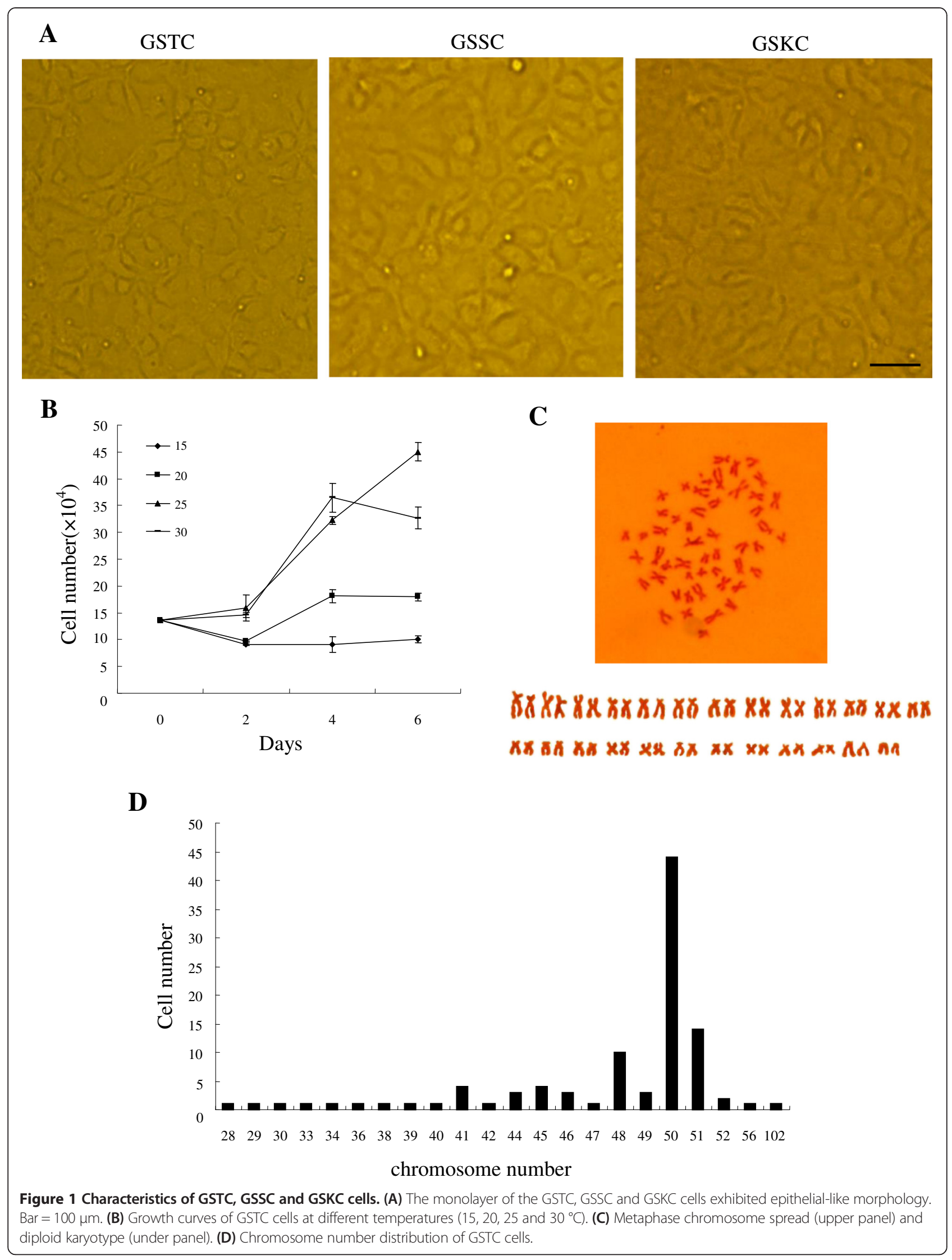



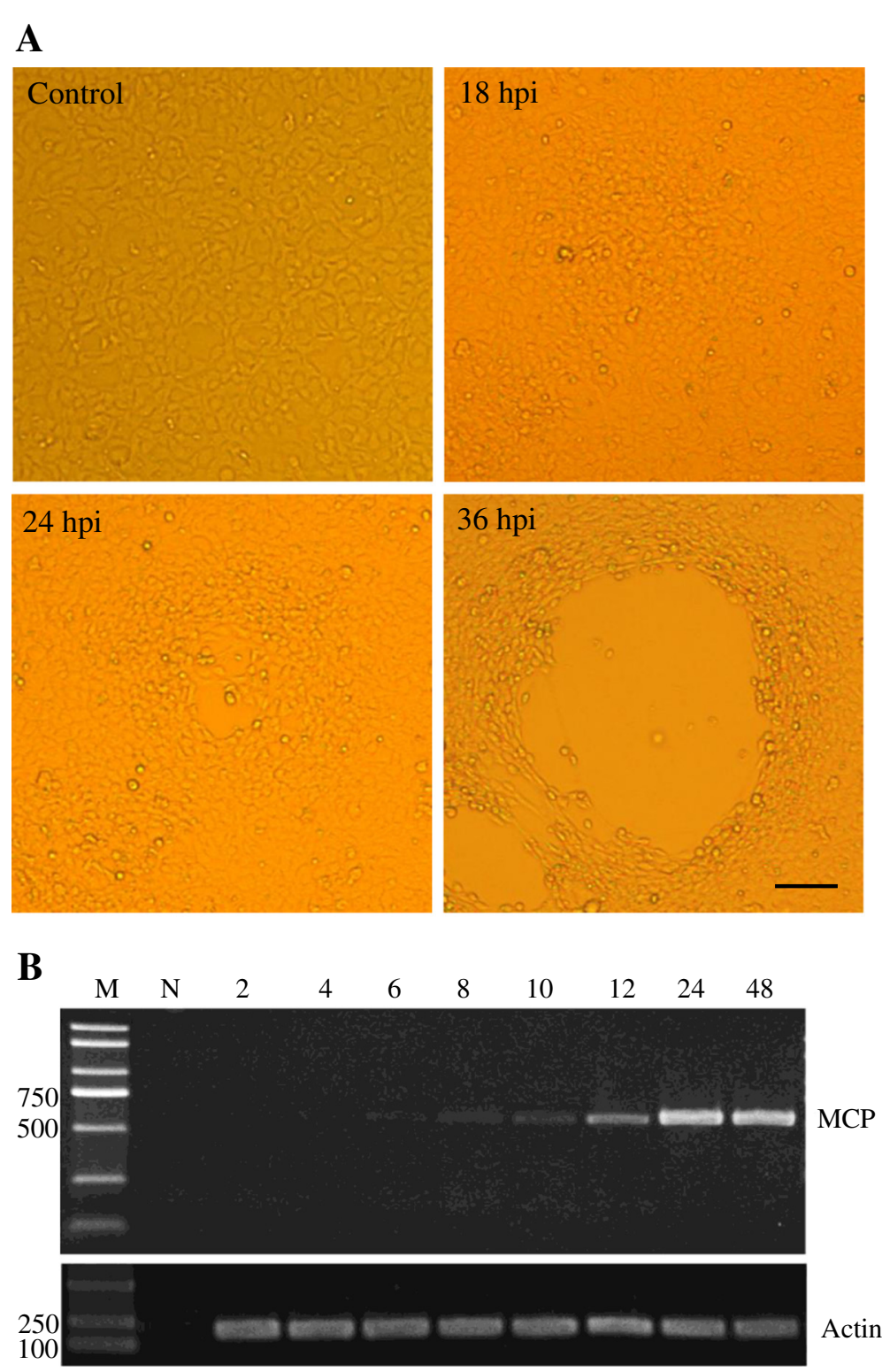

Figure 2 Microscopic observation and RT-PCR analysis. (A) Micrographs of ADRV-infected GSTC cells. Mock-infected (Control) and infected GSTC cells at 18, 24 and $36 \mathrm{hpi}$ were photographed. Bar $=200 \mu \mathrm{m}$. (B) RT-PCR analysis of temporal transcription dynamics of MCP gene in ADRV-infected GSTC cells. Samples were taken from mock-infected (N) and infected GSTC cells at time points of 2, 4, 6, 8, 10, 12, 24 and 48 hpi. Beta-actin (Actin) was used as a positive control.

under light microscopy. In addition, the rRGV-EGFPinfected cells emitted strong green fluorescence signal under fluorescence microscopy (Figure 3). Thus the infection process of rRGV-EGFP in GSTC cells can be directly observed by an alternative way. Our study suggests that GSTC cells are sensitive host cells for recombinant RGV replication.

For electron microscopy observation, ADRV-infected GSTC cells were harvested after appearance of 20\% CPE, and trypsinized with $0.25 \%$ trypsin prior to centrifugation. The pellet was used for subsequent electron microscopy as we previously did [24]. The ultra thin sections were double stained with saturated aqueous uranyl acetate and lead citrate, and examined with an electron microscope (JEM-1230, JEOL, Tokyo, Japan). Electron micrograph of ADRV infected cell shows severe deformation of the nucleus $(\mathrm{N})$, viromatrix $(\mathrm{VM})$ regions with low electron density, small or large crystalline arrays of virus particles (CA) outside the viromatrix, and only a few scattered viral particles within viromatrix. In addition, budding of ADRV particles from the plasma membrane of infected cells were also seen (Figure 4). 


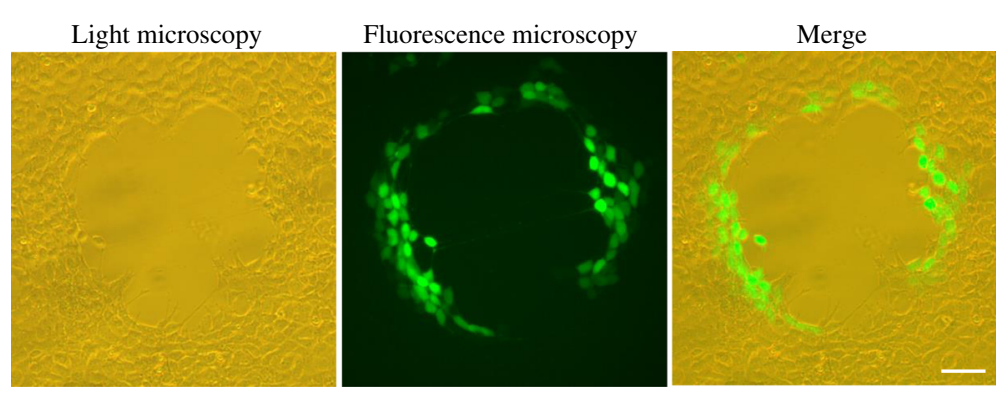

Figure 3 Light microscopy and fluorescent microscopy observations of rRGV-infected GSTC cells. Infected GSTC cells not only showed CPE, but also emitted a green fluorescence signal. Bar $=100 \mu \mathrm{m}$.

\section{Discussion}

In this study, three cell lines from the Chinese giant salamander, namely the thymus cell line (GSTC), spleen cell line (GSSC), and kidney cell line (GSKC) were developed. Among them, GSTC is the first reported cell line that was established from amphibian thymus tissue, the central immune organ of amphibians [28]. More than 280 cell lines have been established from fishes [24], while there has been no report about a permanent cell line from the Chinese giant salamander. Although most of the established amphibian cell lines grow well in L15 medium [25,26], Chinese giant salamander primary cells failed to be cultivated in L15 or MEM medium. We finally chose the TC199 medium which is usually used to cultivate fish cell lines. Additionally, it takes more time for primary cells to migrate from Chinese giant salamander tissues (about a month) than fish primary cells (about one to two weeks) [24,27]. This is likely to be the reason that the Chinese giant salamander cells take longer to adapt in TC199 medium. The chromosome number in GSTC cells ranged from 28 to 102 with asymmetrical distribution, and the

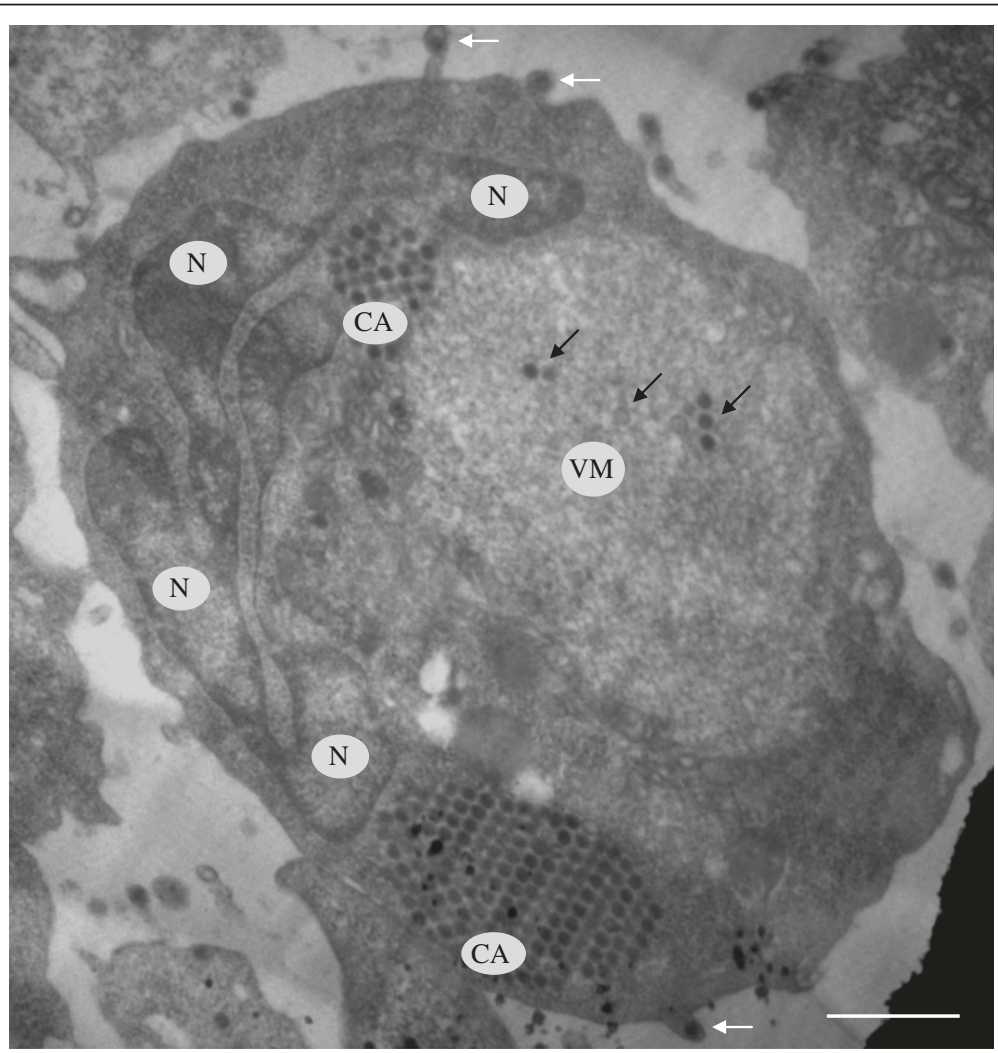

Figure 4 Electron microscopy observations of ADRV-infected GSTC cells. Electron micrograph shows the deformed nucleus (N) and low electron density viromatrix (VM) with small or large crystalline arrays (CA) of ADRV viral particles. Some viral particles were budding from GSTC cell (white arrows). A few scattered viral particles were observed within VM (black arrows). Bar $=1 \mu \mathrm{m}$. 
modal number was 50, which occupies $44 \%$ in the 100 metaphase cells.

In this study, the sensitivities of three cell lines to ADRV were compared by examining cytopathic effects and viral propagations (virus titers). The appearance of CPE in GSTC cells was faster (24 hpi) and more significant than that in GSSC and GSKC cells (appearing at 36 hpi, data not shown). The highest titer of ADRV $\left(10^{8.4} \mathrm{TCID}_{50} / \mathrm{mL}\right)$ was also detected in GSTC cells at 7 days post infection. Collectively, these results suggest that GSTC cells are most sensitive to ADRV. This research also shows that the rRGV-EGFP expressed green fluorescent protein after infecting GSTC cells, which provides a convenient way to observe the infection site and development of CPE. It suggests that the GSTC was suitable for recombinant RGV in vitro infection and gene expression. In addition, these cell lines have been used to analyse interactions between ranavirus and the host, the expression profiles and antiviral activity of amphibian immune genes as we have reported before, which confirms that the infection of GSTC cells with ADRV could induce up-regulations of major histocompatibility complex (MHC) isoforms, IFN-inducible protein 6 (IFI6) and $\mathrm{T}$ cell receptor beta chain (TCR $\beta)[29,30]$.

In summary, we developed three cell lines from the Chinese giant salamander, and the sensitivities of the three cell lines to amphibian ranaviruses were studied. The results show that both wild-type ranavirus ADRV and recombinant ranavirus rRGV-EGFP can replicate and cause CPE in their infected cells, and GSTC has the highest sensitivity to ADRV. Our work provides useful tools for the future study of ADRV, such as identifying ADRV-specific receptors, elucidating the infection mechanism, ADRV recombination and host-pathogen interaction research.

\section{Abbreviations \\ GSTC: Chinese giant salamander thymus cell line; GSSC: Chinese giant salamander spleen cell line; GSKC: Chinese giant salamander kidney cell line; ADRV: Andria davidianus ranavirus; rRGV-EGFP: recombinant Rana grylio virus carrying enhanced green fluorescent protein; MCP: Major capsid protein; FBS: Fetal bovine serum; CPE: Cytopathic effect; hpi: hours post infection; RT-PCR: reverse transcription polymerase chain reaction.}

\section{Competing interests}

The authors declare that they have no competing interests.

\section{Authors' contributions}

QYZ conceived and designed the experiments; JDY, ZYC, XH and XCG performed the experiments; QYZ and JDY analyzed the data; JDY, ZYC and QYZ contributed reagents/materials/analysis tools; JDY and QYZ wrote the paper. All authors read and approved the final manuscript.

\section{Acknowledgements}

This work is supported by grants from the National Natural Science Foundation of China (31430091, 3141101038), the National Key Basic Research Program (2010CB126303), and the Project of State Key Laboratory of Freshwater Ecology and Biotechnology (2011FBZ12).
Received: 24 November 2014 Accepted: 24 April 2015

Published online: 12 June 2015

\section{References}

1. Gao KQ, Shubin NH (2003) Earliest known crown-group salamanders. Nature 422:424-428

2. Wang XM, Zhang KJ, Wang ZH, Ding YZ, Wu W, Huang S (2004) The decline of the Chinese giant salamander Andrias davidianus and implications for its conservation. Oryx 38:197-202

3. Chinchar VG, Waltzek TB (2014) Ranaviruses: not just for frogs. PLoS Pathog 10:e1003850

4. Gui JF, Zhu ZY (2012) Molecular basis and genetic improvement of economically important traits in aquaculture animals. Chin Sci Bull 57:1751-1760

5. Haislip NA, Gray MJ, Hoverman JT, Miller DL (2011) Develepment and disease: how susceptibility to an emerging pathogen changes through anuran devepepment. PLoS One 6:e22307

6. Miller DL, Gray MJ (2010) Amphibian decline and mass mortality: the value of visualizing ranavirus in tissue sections. Vet J 186:133-134

7. Zhang QY, Ruan HM, Li ZQ, Yuan XP, Gui JF (2003) Infection and propagation of lymphocystis virus isolated from the cultured flounder Paralichthys olivaceus in grass carp cell lines. Dis Aquat Organ 57:27-34

8. Chinchar VG (2002) Ranaviruses (family Iridoviridae): emerging cold-blooded killers. Arch Virol 147:447-470

9. Qin QW, Lam TJ, Sin YM, Shen H, Chang SF, Ngoh GH, Chen CL (2001) Electron microscopic observations of a marine fish iridovirus isolated from brown-spotted grouper, Epinephelus tauvina. J Virol Methods 98:17-24

10. Stöhr AC, Blahak S, Heckers KO, Wiechert J, Behncke H, Mathes K, Günther P, Zwart P, Ball I, Rüschoff B, Marschang RE (2013) Ranavirus infections associated with skin lesions in lizards. Vet Res 44:84

11. Chen ZY, Gui JF, Gao XC, Pei C, Hong YJ, Zhang QY (2013) Genome architecture changes and major gene variations of Andrias davidianus ranavirus (ADRV). Vet Res 44:101

12. Dong WZ, Zhang XM, Yang CM, An JH, Qin JZ, Song FF, Zeng WX (2011) Iridovirus infection in Chinese giant salamanders, China, 2010. Emerg Infect Dis 17:2388-2389

13. Geng Y, Wang KY, Zhou ZY, Li CW, Wang J, He M, Yin ZQ, Lai WM (2011) First report of a ranavirus associated with morbidity and mortality in farmed Chinese giant salamanders (Andrias davidianus). J Comp Pathol 145:95-102

14. Li W, Zhang X, Weng XP, Zhao GX, He JG, Dong CF (2014) Virion-associated viral proteins of a Chinese giant salamander (Andrias davidianus) iridovirus (genus Ranavirus) and functional study of the major capsid protein (MCP). Vet Microbiol 172:129-139

15. Zhang QY, Xiao F, Li ZQ, Gui JF, Mao J, Chinchar VG (2001) Characterization of an iridovirus from the cultured pig frog Rana grylio with lethal syndrome. Dis Aquat Organ 48:27-36

16. He LB, Ke F, Zhang QY (2012) Rana grylio virus as a vector for foreign gene expression in fish cells. Virus Res 163:66-73

17. He LB, Gao XC, Ke F, Zhang QY (2013) A conditinal lethal mutation in Rana grylio virus ORF $53 \mathrm{R}$ resulted in marked redution in virion formation. Virus Res 177:194-200

18. Huang X, Pei C, He LB, Zhang QY (2014) The construction of a novel recombinant virus $\triangle 67 R-R G V$ and preliminary analyses of the function of the 67R gene. Bing Du Xue Bao 30:495-501 (in Chinese)

19. Biacchesi S, Lamoureux A, Mérour E, Bernard J, Brémont M (2010) Limited interference at the early stage of infection between two recombinant novirhabdoviruses: viral hemorrhagic septicemia virus and infectious hematopoietic necrosis virus. J Virol 84:10038-10050

20. Zhang QY, Gui JF (2012) Cell and tissue culture in aquatic animals. In: Zhang QY, Gui JF (eds) Atlas of aquatic viruses and viral diseases, vol 2. Science Press, Beijing, pp 47-69

21. Goldsmith CS, Ksiazek TG, Rollin PE, Comer JA, Nicholson WL, Peret T, Erdman DD, Bellini WJ, Harcourt BH, Rota PA, Bhatnagar J, Bowen MD, Erickson BR, McMullan LK, Nichol ST, Shieh WJ, Paddock CD, Zaki SR (2013) Cell culture and electron microscopy for identifying viruses in diseases of unknown cause. Emerg Infect Dis 19:886-891

22. Leland DS, Ginocchio CC (2007) Role of cell culture for virus detection in the age of technology. Clin Microbiol Rev 20:49-78

23. Khan FA (2011) Biotechnology fundamentals. CRC Press, New York

24. Lei XY, Chen ZY, He LB, Pei C, Yuan XP, Zhang QY (2012) Characterization and virus susceptibility of a skin cell line from red-spotted grouper (Epinephelus akaara). Fish Physiol Biochem 38:1175-1182 
25. Sinzelle $L$, Thuret $R$, Hwang HY, Herszberg B, Pailard E, Bronchain OJ Stemple DL, Dhorine-Pollet S, Pollet N (2012) Characterization of a novel Xenopus tropicalis cell line as a model for in vitro studies. Genesis 50:316-324

26. Ferretti P, Brockes JP (1988) Culture of newt cells from different tissues and their expression of a regeneration-associated antigen. J Exp Zool 247:77-91

27. Ou T, Lei XY, He LB, Zhou FJ, Zhang QY (2014) Development of an Ussuri catfish Pseudobagrus ussuriensis skin cell line displaying differential cytopathic effects to three aquatic animal viruses. Virus Res 189:56-62

28. Volpe EP, Turpen JB (1975) Thymus: central role in the immune system of the frog. Science 190:1101-1103

29. Zhang Q, Gui JF (2015) Virus genomes and virus-host interactions in aquaculture animals. Sci China Life Sci 58:156-169

30. Zhu R, Chen ZY, Wang J, Yuan JD, Liao XY, Gui JF, Zhang QY (2014) Thymus cDNA library survey uncovers novel features of immune molecules in Chinese giant salamander Andrias davidianus. Dev Comp Immunol 46:413-422

\section{Submit your next manuscript to BioMed Central and take full advantage of:}

- Convenient online submission

- Thorough peer review

- No space constraints or color figure charges

- Immediate publication on acceptance

- Inclusion in PubMed, CAS, Scopus and Google Scholar

- Research which is freely available for redistribution 